\section{Effects of Preplant Potassium Sources and Rates for Tomato Production}

\author{
Bielinski M. Santos ${ }^{1}$
}

AdDITIONAL INDEX WORDs. Solanum lycopersicum, sulfate of potash, muriate of potash, soil fertility, nutrient management, crop nutrition, yield response

SuMMARY. A two-season study was conducted to assess the effects of preplant potassium (K) fertilization rates and sources on the growth and yield of beefsteak tomato (Solanum lycopersicum). Fourteen treatments resulted from the combination of two K sources: sulfate of potash [SOP $(0 \mathrm{~N}-0 \mathrm{P}-42 \mathrm{~K})$ ] and muriate of potash [MOP (potassium chloride, $0 \mathrm{~N}-0 \mathrm{P}-50 \mathrm{~K})]$ and seven preplant $\mathrm{K}$ rates $(0,50,100,200,300$, 400, and $500 \mathrm{lb} /$ acre). Soil electrical conductivity (EC) at 4 weeks after transplanting was influenced by the interaction between preplant $\mathrm{K}$ rates and sources. When SOP was applied, soil EC increased from $0.4 \mathrm{dS} \cdot \mathrm{m}^{-1}$ with no preplant $\mathrm{K}$ application to $\approx 1.3 \mathrm{dS} \cdot \mathrm{m}^{-1}$ with a rate of $500 \mathrm{lb} /$ acre of preplant $\mathrm{K}$. However, the soil EC steadily increased from 0.4 to $3.0 \mathrm{dS} \cdot \mathrm{m}^{-1}$ as preplant $\mathrm{K}$ rates increased from 0 to $500 \mathrm{lb} / \mathrm{acre}$ when MOP was used as the nutrient source. The combined effect of the preplant application of $\mathrm{K}$ rates and sources influenced the seasonal extra-large and total marketable fruit weight, which increased steadily with $K$ rates, regardless of the sources, from 0 to $300 \mathrm{lb} / \mathrm{acre}$. At K rates between 300 and $500 \mathrm{lb} / \mathrm{acre}$, there were no extra-large and total fruit weight differences among rates when SOP was applied. In contrast, extra-large and total marketable fruit weight declined when rates increased from 300 to $500 \mathrm{lb} /$ acre of K and MOP was applied to the soil. Data demonstrated that plots treated with MOP at rates higher than $300 \mathrm{lb} /$ acre of $\mathrm{K}$ increased soil EC and caused a decline on extra-large and total marketable fruit weight of tomato.

$\mathrm{O}$ pen-field tomato production in Florida occurs on $\approx 32,000$ acres and generates above $\$ 630$ million in gross sales (U.S. Department of Agriculture, 2011). Potassium is one of the two most-absorbed essential elements for tomato growth and development (Carpena et al., 1988; Chapagain et al., 2003; Chen and Gabelman, 1999; Tapia and Gutierrez, 1997). Tomato crop uptake could exceed $300 \mathrm{~kg} \cdot \mathrm{ha}^{-1}$ of $\mathrm{K}$ and the majority is translocated to the fruit (Hartz et al., 2002; Widders and Lorenz, 1979). This nutrient is essential for $\mathrm{pH}$ stabilization, osmoregulation, enzyme activation, and membrane integrity (Marschner, 1995). In addition to stomatal regulation during transpiration and photosynthesis, $\mathrm{K}$ is also involved in photophosphorylation, transport of photoassimilates from source tissues via the phloem to sink tissues, and stress tolerance (Doman and Geiger, 1979; Marschner, 1995; Pettigrew, 2008; Usherwood, 1985). Deficiencies of $\mathrm{K}$ are associated with a number of economically significant physiological disorders of tomato fruit,

Gulf Coast Research and Education Center, IFAS University of Florida, 14625 County Road 672, Wimauma, FL 33598

${ }^{1}$ Corresponding author. E-mail: bmsantos@ufl.edu. including greenback, blotchy ripening, and graywall (Forster, 1973; Picha and Hall, 1981). Excessive K fertilization depresses calcium $(\mathrm{Ca})$ and magnesium uptake, leading to other serious disorders such as blossom end rot and increasing total rhizosphere salts to potentially yield-limiting levels.

In the majority of tomato production areas in Florida, soils are fine sands with very low organic matter content and rapid infiltration. Because of these edaphic characteristics, efficient irrigation and fertilization are considerable challenges for commercial growers. The vast majority of tomato farms set transplants in polyethylenemulched fumigated beds that are grown with one of two irrigation systems: seepage (subsurface) or seepage plus drip. In the latter system, fertilizer applications are generally split between granular preplant formulas and inseason liquid injection through the drip lines, whereas in the former, the nutrients are applied exclusively before planting. Preplant fertilizers for tomato production are applied in two procedures: 1) broadcast to the soil ("cold mix") before bed pressing and 2) banded on bed tops ("hot mix"). The "cold mix" usually consists of $25 \%$ to $35 \%$ of the total nitrogen $(\mathrm{N})$ and $\mathrm{K}$, and all the needed micronutrients. The rest of the $\mathrm{N}$ and $\mathrm{K}$ are applied in one or two bands on bed tops.

Tomato growers obtain granular fertilizer from commercial suppliers that blend formulas according to soil analysis recommendations and use SOP $(0 \mathrm{~N}-0 \mathrm{P}-42 \mathrm{~K}-17 \mathrm{~S})$, MOP (potassium chloride, $0 \mathrm{~N}-0 \mathrm{P}-50 \mathrm{~K}$ ), and potassium nitrate $(13 \mathrm{~N}-0 \mathrm{P}-37 \mathrm{~K})$ as the most common $\mathrm{K}$ sources. However, MOP has a very elevated salt index ( salt index $=116)$, mainly because of its high chloride content, in comparison with that for SOP (salt index $=$ 46), which could lead to leaf burning (Grattan and Maas, 1988; Marchand and Abd El Hadi, 2002; Maynard and Hochmuth, 2007). Furthermore, when chlorine soil levels are high enough to be toxic, $\mathrm{K}$ absorption decreases because of disordered cell metabolism (Chen et al., 2010). Elevated soil EC is directly linked to crop injury and reduced water and nutrient absorption in most crops. It has been indicated that a soil EC around $2.5 \mathrm{dS} \cdot \mathrm{m}^{-1}$ is unsuitable for most crops to achieve acceptable yields (Maynard and Hochmuth, 2007; White and Broadley, 2001). When all or the majority of preplant $\mathrm{K}$ is derived from MOP, high salt injury has been observed routinely in tomato fields located in southwestern and west-central Florida, which has forced growers to be careful when

\begin{tabular}{llll}
\hline $\begin{array}{l}\text { Units } \\
\text { To convert U.S. to SI, } \\
\text { multiply by }\end{array}$ & U.S. unit & SI unit & $\begin{array}{l}\text { To convert SI to U.S., } \\
\text { multiply by }\end{array}$ \\
\hline 0.4047 & acre(s) & $\mathrm{ha}$ & 2.4711 \\
0.3048 & $\mathrm{ft}$ & $\mathrm{m}$ & 3.2808 \\
9.3540 & gal/acre & $\mathrm{L} \cdot \mathrm{ha}^{-1}$ & 0.1069 \\
2.54 & inch $(\mathrm{es})$ & $\mathrm{cm}$ & 0.3937 \\
25.4 & inch $(\mathrm{es})$ & $\mathrm{mm}$ & 0.0394 \\
0.4536 & lb & $\mathrm{kg}$ & 2.2046 \\
1.1209 & $\mathrm{lb} / \mathrm{acre}$ & $\mathrm{kg} \cdot \mathrm{ha}^{-1}$ & 0.8922 \\
1 & $\mathrm{mmho} / \mathrm{cm}$ & $\mathrm{dS} \cdot \mathrm{m}^{-1}$ & 1 \\
28.3495 & $\mathrm{oz}$ & $\mathrm{g}$ & 0.0353 \\
1 & $\mathrm{ppm}$ & $\mathrm{mg} \cdot \mathrm{kg}^{-1}$ & 1 \\
2.2417 & ton/acre & $\mathrm{Mg} \cdot \mathrm{ha}^{-1}$ & 0.4461
\end{tabular}


applying this $\mathrm{K}$ source, especially at high $\mathrm{K}$ rates. Based on standard $\mathrm{K}$ fertilizer prices, there are potential savings from providing this nutrient from MOP rather than using other sources (Chapagain et al., 2003).

Previous research studied the effects of $\mathrm{K}$ sources and rates on tomato growth and yield. Locascio et al. (1997) tested three $\mathrm{K}$ sources and determined that there were no differences on midseason tomato leaf $\mathrm{K}$ concentrations and fruit yield and size. Rate studies indicated that preplant $\mathrm{K}$ fertilization significantly decreased yellow shoulder, internal white tissue, and total color defects in processing tomato at doses of 185 and $370 \mathrm{~kg} \cdot \mathrm{ha}^{-1}$ (Hartz et al., 1999). Locascio et al. (1997) showed that with broadcast preplant $\mathrm{K}$ fertilization and drip irrigation, maximum yields were produced with 75 to $150 \mathrm{~kg} \cdot \mathrm{ha}^{-1}$ of $\mathrm{K}$, whereas with the application of $\mathrm{K}$ in double bands on bed shoulders and with subsurface irrigation, maximum yields were obtained with 225 to $300 \mathrm{~kg} \cdot \mathrm{ha}^{-1}$ of $\mathrm{K}$, more than the amount of $\mathrm{K}$ recommended by soil tests. Taber et al. (2008) determined that the effect of $\mathrm{K}$ rates was evident at each harvest with high $\mathrm{K}$ fertilization $\left(373 \mathrm{~kg} \cdot \mathrm{ha}^{-1}\right)$ giving a largest total accumulative tomato marketable yield in comparison with lower Krates.

In Florida, K application rates have changed dramatically during the last decade. Informal surveys among tomato growers indicated that between 400 and $550 \mathrm{lb} /$ acre of $\mathrm{K}$ were applied per season a decade ago, whereas now only between 250 and $350 \mathrm{lb} /$ acre are used. This is partially due to the steady increase of worldwide fertilizer prices, and specifically because traditionally SOP has been more expensive than MOP, which are two of the most frequently used K sources in Florida (U.S. Department of Agriculture, 2012). Therefore, this situation opens an opportunity to re-evaluate the use of MOP in K fertilizer blends at lower rates than those used at the beginning of the current century. The objective of this study was to compare the effects of $\mathrm{K}$ sources and rates on the tomato fruit yield, foliar $\mathrm{K}$ concentrations, and soil EC.

\section{Materials and methods}

Two field studies were conducted during Fall 2009 and 2010 at the Gulf Coast Research and Education Center of the University of Florida in Balm.
The soil at the experimental site is a sandy, siliceous, hyperthermic Oxyaquic Alorthod with $<1.5 \%$ organic matter, $\mathrm{pH}$ of 6.8 , and EC of $0.3 \mathrm{dS} \cdot \mathrm{m}^{-1}$. Before the experiment, the soil was tilled twice at an approximate depth of 8 inches to ensure suitable conditions for bed preparation. The soil at the experimental site was low in $\mathrm{K}$ $(<20 \mathrm{ppm})$, as revealed by soil tests conducted 1 month before the studies. A standard bedder was used to create raised beds that were $5 \mathrm{ft}$ apart at the center, 8 inches high, 28 inches wide across the top, and 32 inches wide at the base. Raised beds were fumigated in the last week of July of each year with a 50:50 (v/v) methyl bromide and chloropicrin mixture at $170 \mathrm{lb} /$ acre to eliminate weeds, nematodes, and soil pathogens. 'Tygress' beefsteak tomato seedlings at the four-true-leaf stage $(\approx 5$ to 6 inches tall) were transplanted on bed centers in a single row with 2 - $\mathrm{ft}$ spacing between plants in the third week of August of each year. Tomato plants were established and grown throughout the season with subsurface (seepage) irrigation only, using daily volumes that fluctuated between 10,000 and $14,000 \mathrm{gal} /$ acre per day, depending on the local potential evapotranspiration and rainfall, as outlined by Simonne and Dukes (2009). Plants were staked and tied four times as described by Csizinszky et al. (2005). All other crop management was conducted according to current recommendations for tomato production in Florida (Olson et al., 2011).

Fourteen treatments resulted from the combination of two $\mathrm{K}$ sources (SOP and MOP) and seven preplant $\mathrm{K}$ rates $(0,50,100,200,300,400$, and $500 \mathrm{lb} / \mathrm{acre})$. These rates were expressed as $\mathrm{K}$ rather than potassium oxide $\left(\mathrm{K}_{2} \mathrm{O}\right)$. Treatments were arranged in a randomized complete block design with six replications. Plots consisted of 20 plants and were separated with 10 -ft-long nonplanted borders. Either SOP $(0 \mathrm{~N}-0 \mathrm{P}-42 \mathrm{~K}$; Compass Minerals, Salt Lake City, UT) or MOP $(0 \mathrm{~N}-0 \mathrm{P}-50 \mathrm{~K})$ was applied on 28 July 2009 and 27 July 2010. Each preplant $\mathrm{K}$ source was weighed in a laboratory and applied by hand as two, 2-inchdeep bands located 12 inches apart on top of raised beds before soil fumigation and plastic mulch application. To avoid confounding effects because of $S$ content in SOP, elemental S $(90 \%$ S, prills of $2.6 \mathrm{~mm}$ in diameter, Tiger 90 CR; Tiger-Sul, Calgary, AB, Canada) was added at the appropriate rates to balance this nutrient across the study. Plant nutrients, such as nitrogen, magnesium, iron, zinc, boron, and manganese were applied under nonlimiting conditions on bed tops using recommended rates based on the interpretation of preseason soil test results (Olson et al., 2011; Simonne and Hochmuth, 2009). Applications of phosphorus (P) and $\mathrm{Ca}$ were not necessary because the soil at the experimental site had sufficient concentrations of these nutrients $\left(>30 \mathrm{mg} \cdot \mathrm{kg}^{-1} \mathrm{P}\right.$ and $>890 \mathrm{~kg} \cdot \mathrm{ha}^{-1} \mathrm{Ca}$ ) as revealed by soil tests conducted 1 month before planting.

Soil samples were collected for soil EC at 4 weeks after transplanting (WAT). Six soil cores, which constituted a soil sample of about $1 \mathrm{lb}$ each, were taken from between tomato plants on the center of raised beds to a depth of 6 inches. To measure soil EC, the 2:1 water to soil extraction method was used as outlined by Mylavarapu (2012). Plant tissue samples for $\mathrm{K}$ leaf concentrations were collected at 4 and 8 WAT using 10 most recently matured tomato leaves adjacent to an inflorescence as suggested by Mills and Jones (1996). Subsample of leaf tissue ( $5 \mathrm{~g}$ each) was submitted to a commercial laboratory (Waters Agricultural Laboratory, Camilla, GA) for total foliar K, which was extracted using the Mehlich-1 extraction procedure and determined using inductively coupled plasma-optical emission spectrophotometry (Mylavarapu, 2012).

Following local practices, maturegreen tomato fruit were harvested twice at 10 and 12 WAT during both seasons, and they were graded as extralarge ( $\geq 2-25 / 32$ inches in diameter) and total marketable, according to the current standards for size categories (Brown, 2011). A marketable fruit was defined as any fruit without blemishes or physical injury and an equatorial diameter of at least 2-9/32 inches. Marketable tomato fruit weight was collected using all plants in each experimental unit and calculated as the summation of all marketable fruit, including the extra-large grade. All collected measurements were subjected to an analysis of variance to determine single factor and interactions significance $(P<0.05)$ using a general linear model, as well as the effects of linear 
and quadratic contrasts through regression analysis (SAS version 9.2; Cary, $\mathrm{NC}$ ). Individual treatment means were separated with standard error bars.

\section{Results and discussion}

There were no significant season by treatment interactions for the collected variables. Therefore, the data from both growing seasons were combined for analysis. Soil EC at 4 WAT was influenced by the interaction between preplant $\mathrm{K}$ rates and sources (Fig. 1A). There were two distinctive linear response trends as preplant $\mathrm{K}$ rates increased for each nutrient source. When SOP was applied, soil EC increased from $0.4 \mathrm{dS} \cdot \mathrm{m}^{-1}$ with no preplant $\mathrm{K}$ application to $\approx 1.3 \mathrm{dS} \cdot \mathrm{m}^{-1}$ with a rate of $500 \mathrm{lb} /$ acre of preplant $\mathrm{K}$. There were no soil EC differences among preplant $\mathrm{K}$ rates between 300 and $500 \mathrm{lb} /$ acre. However, the soil
EC steadily increased from 0.4 to 3.0 $\mathrm{dS} \cdot \mathrm{m}^{-1}$ as preplant $\mathrm{K}$ rates increased from 0 to $500 \mathrm{lb} /$ acre when MOP was used as the nutrient source.

Foliar K concentrations at 4 WAT were interactively affected by the two factors and responded quadratically to the application of $\mathrm{K}$ rates (Fig. IB). Application of both preplant K sources resulted on the same foliar $\mathrm{K}$ concentrations at 4 WAT when $\mathrm{K}$ rates were between 0 and $400 \mathrm{lb} /$ acre. In contrast, application of MOP at 500 $\mathrm{lb} /$ acre of $\mathrm{K}$ caused lower foliar K concentration $(2.5 \% \mathrm{~K})$ than when SOP was used at the same $\mathrm{K}$ rate $(3.8 \% \mathrm{~K})$. When SOP was used as the K source, there were no differences on the foliar $\mathrm{K}$ concentrations when application rates were between 300 and 500 $\mathrm{lb} /$ acre of K. Regardless of K sources, application of this nutrient at rates of $200 \mathrm{lb} /$ acre or higher resulted in foliar $\mathrm{K}$ concentrations at or above $2.5 \%$, which is the current recommendation for 4-week-old tomato plants in Florida (Olson et al., 2011). At 8 WAT, foliar $\mathrm{K}$ concentrations increased linearly with $\mathrm{K}$ rates. There was no significant $K$ source by rate interaction or $\mathrm{K}$ source effect on foliar $\mathrm{K}$ concentrations. However, $\mathrm{K}$ rates had a distinct effect on foliar $\mathrm{K}$ concentrations, which ranged between $1.2 \%$ to slightly less than $3 \% \mathrm{~K}$ as rates increased from 0 to $500 \mathrm{lb} /$ acre (Fig. 1C). Foliar concentration of $\mathrm{K}$ increased at or above $2.5 \%$ during tomato blooming when rates of $200 \mathrm{lb} /$ acre of $\mathrm{K}$ or higher were applied to the plots. This K concentration is the sufficiency threshold for this nutrient as suggested by Olson et al. (2011). This finding indicated that K supply was not a growth-limiting factor in this study and did not hinder crop performance.
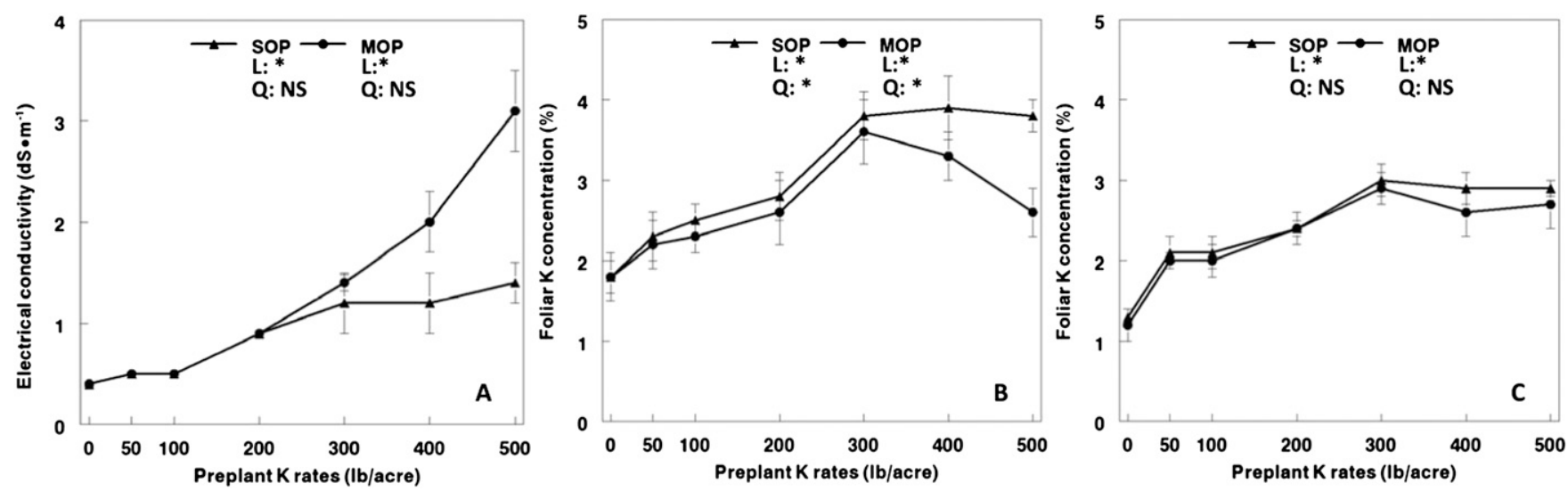

Fig. 1. (A) Effects of preplant potassium (K) rates and sources [sulfate of potash (SOP), muriate of potash (MOP)] on electrical conductivity at 4 weeks after transplanting, and foliar $K$ concentrations at 4 and 8 weeks after transplanting (B and $C$, respectively). Treatment effects tested with regression analysis and significant means compared with $S E$ values; $L=1$ linear effects, $Q=q u a d r a t i c$ effects; $\mathrm{NS},{ }^{*}=$ Nonsignificant and significant at $P<0.05$, respectively; $1 \mathrm{lb} /$ acre $=1.1209 \mathrm{~kg} \cdot \mathrm{ha}^{-1}, 1 \mathrm{dS} \cdot \mathrm{m}^{-1}=1 \mathrm{mmho} / \mathrm{cm}$.
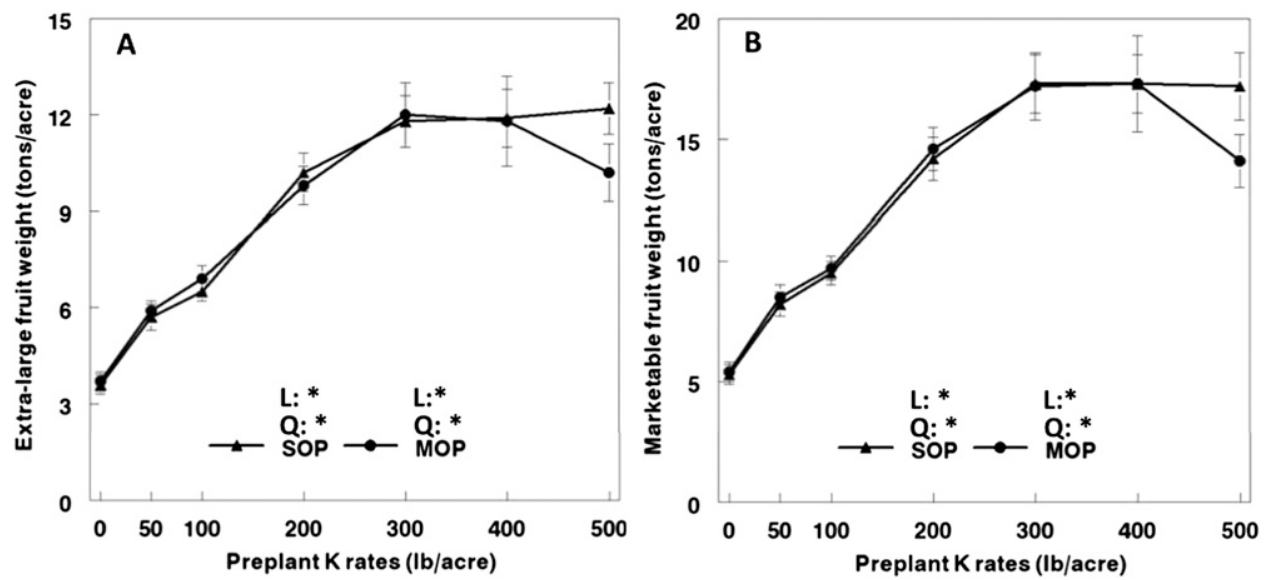

Fig. 2. (A) Effects of preplant potassium (K) rates and sources [sulfate of potash (SOP), muriate of potash (MOP)] on extralarge and (B) total marketable fruit weight of tomatoes. Treatment effects tested with regression analysis and significant means compared with SE values; $L=$ linear effects, $Q=$ quadratic effects; $N$, * = Nonsignificant and significant at $P<0.05$, respectively; $1 \mathrm{lb} /$ acre $=1.1209 \mathrm{~kg} \cdot \mathrm{ha}^{-1}, 1$ ton $/$ acre $=2.2417 \mathrm{Mg} \cdot \mathrm{ha}^{-1}$. 
The combined effect of the preplant application of $\mathrm{K}$ rates and sources influenced the seasonal extra-large and total marketable fruit weight, both of which responded quadratically to $\mathrm{K}$ rates. Extra-large fruit weight increased steadily with $\mathrm{K}$ rates, regardless of the sources, from 0 to $300 \mathrm{lb} /$ acre, ranging between 3.5 and 12.0 tons/acre (Fig. 2A). When plots were applied with K rates between 300 and $500 \mathrm{lb} / \mathrm{acre}$, two distinctive response patterns were observed. First, there were no significant extra-large fruit weight differences among rates when SOP was applied to the plots, averaging 12.0 tons/acre. In contrast, extralarge fruit weight declined from 12.0 to 10.0 tons/acre when rates increased from 300 to $500 \mathrm{lb} /$ acre of $\mathrm{K}$ and MOP was applied to the soil. For total marketable fruit weight, the highest yield values (17.4 tons/acre) were obtained with the preplant application of 300 to $400 \mathrm{lb} /$ acre of $\mathrm{K}$, regardless of the nutrient sources (Fig. 2B). Furthermore, there were no total marketable fruit weight differences when plots were treated with SOP rates between 300 and $500 \mathrm{lb} / \mathrm{acre}$, averaging 17.4 tons/acre. In comparison, a $15 \%$ decline in total marketable fruit weight occurred when preplant $\mathrm{K}$ rates increased from 400 to $500 \mathrm{lb} /$ acre and MOP was used as the nutrient source.

These results demonstrated that plots treated with MOP at rates higher than $300 \mathrm{lb} /$ acre of $\mathrm{K}$ increased soil EC and caused a decline on extra-large and total marketable fruit weight of tomato. Those soil EC values surpassed the reference soil EC threshold for tomato production with a maximum of $2.5 \mathrm{dS} \cdot \mathrm{m}^{-1}$ (Maynard and Hochmuth, 2007). Although rate dependent, MOP is still a viable source for partially replacing SOP in preplant $\mathrm{K}$ fertilizer blends for tomato, especially at rates lower than $400 \mathrm{lb} /$ acre of $\mathrm{K}$, which could reduce production costs for growers. However, growers should exercise caution when applying high $\mathrm{K}$ rates with MOP.

\section{Literature cited}

Brown, R.L. 2011. Florida Tomato Committee: Regulatory Bulletin No. 1. 20 Nov. 2011. <http://www.floridatomatoes. org/Regulations/Domestic-Markets.aspx>.

Carpena, O., A. Masaguer, and M.J. Sarro. 1988. Nutrient uptake by two cultivars of tomato plants. Plant Soil 105:294-296.
Chapagain, B.P., Z. Wiesman, M. Zaccai, P. Imas, and H. Magen. 2003. Potassium chloride enhances fruit appearance and improves quality of fertigated greenhouse tomato as compared to potassium nitrate. J. Plant Nutr. 26:643-658.

Chen, J. and W.H. Gabelman. 1999. Potassium-transport rate from root to shoot unrelated to potassium-use efficiency in tomato grown under low-potassium stress. J. Plant Nutr. 22:621-631.

Chen, W., Z.L. He, X.E. Yang, S. Mishra, and P.J. Stoffella. 2010. Chlorine nutrition of higher plants: Progress and perspectives. J. Plant Nutr. 33:943-952.

Csizinszky, A.A., D.J. Schuster, J.B. Jones, and J.C. van Lenteren. 2005. Crop production, p. 237-256. In: E. Heuvelink (ed.) Tomatoes. CABI Publ., Cambridge, MA

Doman, D.C. and D.R. Geiger. 1979. Effect of exogenously supplied foliar potassium on phloem loading in Beta vulgaris L. Plant Physiol. 64:528-533.

Forster, H. 1973. Relationship between the nutrition and the appearance of 'greenback' and 'blossom-end rot' in tomato fruits. Acta Hort. 29:319-326.

Grattan, S.R. and E.V. Maas. 1988. Effect of salinity on phosphate accumulation and injury in soybean. II: Role of substrate $\mathrm{Cl}$ and Na. Plant Soil 109:65-71.

Hartz, T.K., C. Giannini, R.O. Miller, and E.M. Miyao. 2002. Estimating soil potassium availability for processing tomato production. Commun. Soil Sci. Plant Anal. 33:1389-1400.

Hartz, T.K., G. Miyao, R.J. Mullen, M.D. Cahn, J. Valencia, and K.L. Brittan. 1999. Potassium requirements for maximum yield and fruit quality of processing tomato. J. Amer. Soc. Hort. Sci. 124:199-204.

Locascio, S.J., G.J. Hochmuth, S.M. Olson, R.C. Hochmuth, A.A. Csizinszky, and K.D. Shuler. 1997. Potassium source and rate for polyethylene-mulched tomatoes. HortScience 32:1204-1207.

Marchand, M. and H. Abd El Hadi. 2002. Long-term experiments comparing the impact on soils and field crops of potassium chloride vs. potassium sulfate. Acta Hort. 573:49-54.

Marschner, H. 1995. Mineral nutrition of higher plants. Academic Press, New York.

Maynard, D.N. and G.J. Hochmuth. 2007. Knott's handbook for vegetable growers. Wiley, Hoboken, NJ.

Mills, H.A. and J.B. Jones. 1996. Plant analysis handbook II. Micro-Macro Publ., Athens, GA.
Mylavarapu, R.S. 2012. UF/IFAS Extension Soil Testing Laboratory (ESTL) analytical procedures and training manual. 18 Mar. 2013. <http://edis.ifas.ufl.edu/ pdffiles/SS/SS31200.pdf>.

Olson, S.M., W.M. Stall, G.E. Vallad, S.E. Webb, S.A. Smith, E.H. Simonne, E. McAvoy, B.M. Santos, and M. OzoresHampton. 2011. Tomato production in Florida, p. 309-332. In: S.M. Olson and B.M. Santos (eds.). Vegetable production handbook for Florida, 2010-2011. Vance Publ., Lenexa, KS.

Pettigrew, W.T. 2008. Effects of K on plant metabolism. Physiol. Plant. 133:670-681.

Picha, D.H. and C.B. Hall. 1981. Influences of potassium, cultivar, and season on tomato graywall and blotchy ripening. J. Amer. Soc. Hort. Sci. 106:704-708.

Simonne, E.H. and M.D. Dukes. 2009. Principles and practices of irrigation management for vegetables, p. 17-23. In: S.M. Olson and E.H. Simonne (eds.). Vegetable production handbook for Florida, 20092010. Vance Publ., Lenexa, KS.

Simonne, E.H. and G.J. Hochmuth. 2009. Soil and fertilizer management for vegetable production in Florida, p. 3-15. In: S.M. Olson and E.H. Simonne (eds.). Vegetable production handbook for Florida, 2009-2010. Vance Publ., Lenexa, KS.

Taber, H., P. Perkins-Veazie, S. Li, W. White, S. Rodermel, and Y. Xu. 2008. Enhancement of tomato fruit lycopene by potassium is cultivar dependent. HortScience 43:159-165.

Tapia, M.L. and V. Gutierrez. 1997. Distribution pattern of dry weight, nitrogen, phosphorus, and potassium through tomato ontogenesis. J. Plant Nutr. 20:783-791.

U.S. Department of Agriculture. 2011. Vegetables 2010 summary. 1 May 2011. <http://usda.mannlib.cornell.edu/usda/ current/VegeSumm/VegeSumm-01-272010.pdf>.

U.S. Department of Agriculture. 2012. Fertilizer use and price. 2 July 2012. <http://www.ers.usda.gov/data-products/ fertilizer-use-and-price.aspx $>$.

Usherwood, N.R. 1985. The role of potassium in crop quality, p. 489-513. In: R.D. Munson (ed.). Potassium in agriculture. Amer. Soc. Agron., Crop Sci. Soc. Amer., Soil Sci. Soc. Amer., Madison, WI.

White, P.J. and M.R. Broadley. 2001. Chloride in soils and its uptake and movement within the plant: A review. Ann. Bot. (Lond.) 88:967-988.

Widders, I.E. and O.A. Lorenz. 1979. Tomato root development as related to potassium nutrition. J. Amer. Soc. Hort. Sci. 104:216-220. 